\title{
Characterization of Nocardithiocin Derivatives Produced by Amino Acid Substitution of Precursor Peptide notG
}

\author{
Kanae Sakai ${ }^{1}$ (D) Yasumasa Hara ${ }^{2} \cdot$ Masami Ishibashi $^{2} \cdot$ Mai Sakai $^{3} \cdot$ Seiya Kawahara $^{3} \cdot$ Susumu Imanishi $^{3}$. \\ Kenichi Harada ${ }^{3}$ - Yasutaka Hoshino ${ }^{4} \cdot$ Hisayuki Komaki $^{5} \cdot$ Akira Mukai $^{6} \cdot$ Tohru Gonoi $^{1}$
}

Accepted: 5 March 2019 / Published online: 25 March 2019

(c) The Author(s) 2019

\begin{abstract}
Nocardithiocin is a thiopeptide compound produced by the pathogenic actinomycete Nocardia pseudobrasiliensis that displays activity against Gram-positive bacteria including drug-resistant Mycobacterium tuberculosis. However, the clinical use of nocardithiocin is hampered by light sensitivity and low water solubility. To improve these properties, the sixth amino acid of core peptide was substituted for other 19 amino acids by modifying the gene sequence of precursor peptide. Ten amino acids were successfully substituted to produce 1-3 novel compounds, of which six were the expected nocardithiocin derivatives. The compounds were tested for their stability, solubility, and antimicrobial activity. Of the 17 compounds produced, ten displayed antibiotic activity and two of them improved MIC value to bacteria. Furthermore, nocardithiocin and all derivatives were stable to the light. The substitution of amino acid sequence in precursor peptide could lead the successful production of nocardithiocin derivatives and alter its property. This report represents the first step of nocardithiocin utilization, and amino acid substitution technique can be used to create desirable nocardithiocin derivatives.
\end{abstract}

Keywords Thiopeptides $\cdot$ Nocardithiocin $\cdot$ Antimicrobial $\cdot$ Mycobacterium tuberculosis $\cdot$ Gene modification

Electronic supplementary material The online version of this article (https://doi.org/10.1007/s10989-019-09836-0) contains supplementary material, which is available to authorized users.

Kanae Sakai

ksakai@people.kobe-u.ac.jp

1 Medical Mycology Research Center, Chiba University, 1-8-1, Inohana, Chuo-ku, Chiba 260-8673, Japan

2 Graduate School, Faculty of Pharmaceutical Science, Chiba University, Chuo-ku, Chiba 260-8673, Japan

3 Faculty of Pharmacy, Meijo University, Tenpaku-ku, Nagoya 468-8503, Japan

4 National Institute of Infectious Diseases, Shimjuku-ku, Tokyo 162-8640, Japan

5 NBRC, National Institute of Technology and Evaluation, Kisarazu, Chiba 292-0818, Japan

6 Graduate School of Pharmaceutical Sciences, Setsunan University, Neyagawa, Osaka 572-8508, Japan

\section{Introduction}

Thiopeptides are natural products derived from ribosomally synthesized post-translationally modified peptides (RiPPs) that possess a variety of biological properties including antimicrobial, antiparasitic, and anticancer activities ( $\mathrm{Li}$ and Kelly 2010; Just-Baringo et al. 2014a). However, their poor pharmacokinetic properties, especially low water solubility, hampers their clinical use. To improve their properties, derivatives have been generated by several ways such as chemical synthesis (Nicolaou et al. 2003; Gross et al. 2013; Just-Baringo et al. 2014b), semi-synthesis (Naidu et al. 2006; Xu et al. 2013), and genetic modification (Bowers et al. 2010; Li et al. 2011, 2012; Young et al. 2012; Zhang and Kelly 2015) (Just-Baringo et al. 2014c). Based on the biosynthetic pathway of RiPPs compounds, DNA sequence of precursor peptide is directly related to their peptide structure (Arndt et al. 2009; Kelly et al. 2009; Morris et al. 2009). So the derivatives production of thiopeptides were achieved relatively easy by modifying the gene sequence of core peptide region among precursor peptide. The increasing information of biosynthetic genes and recent progress in the development of genetic tools and techniques have made 
thiopeptides more attractive as novel lead compounds for pharmaceutical agents.

Nocardithiocin is a thiopeptide compound produced by Nocardia pseudobrasiliensis that displays antimicrobial activity against Gram-positive bacteria, especially acid-fast bacteria (Fig. 1a) (Mukai et al. 2009). Impressive antimicrobial activity against drug-resistant Mycobacterium tuberculosis has resulted in significant attention to the gene cluster responsible for nocardithiocin biosynthesis (Sakai et al. 2015). Gene disruption and expression analysis revealed a $15.2 \mathrm{~kb}$ cluster of 12 genes including precursor peptide $(n o t G)$, as well as post-transcriptional modification enzymes that modify the peptide structure (Fig. 2a).

Like other thiopeptides, nocardithiocin is poorly soluble in water and light sensitivity was reported (Mukai et al. 2009). Herein, we attempted to improve its properties by genetic modification without diminishing its antibiotic activity. Although the actual mode of action of nocardithiocin is not elucidated yet, a number of 26-membered macrocycles thiopeptides including thiostrepton, noshiheptide, and micrococcin have been reported that interaction with ribosomal protein L11 as well as 23S rRNA through a Threonine residue (highlighted in red in Fig. 1a) cause antimicrobial activity (Bowers et al. 2010; Acker et al. 2009; Tran et al.
2017). Residues $S_{1}, C_{9}, S_{10}, C_{11}$, and $T_{3}$ of nocardithiocin precursor peptide were thought to be related to retention of the macrocyclic structure and antimicrobial activity, respectively (Fig. 2b). In the present study, the sixth amino acid $\left(\mathrm{V}_{6}\right)$ of the core peptide which exist at distal position from pyridine ring was selected to replace with the other 19 amino acids and the properties and antimicrobial activity of the derivatives were assessed.

\section{Materials and Methods}

\section{Strains and Cultivation Conditions}

Nocardithiocin producer N. pseudobrasiliensis IFM 0761 was obtained from Medical Mycology Research Center (MMRC), Chiba University, Japan. Escherichia coli DH5 was used for construction and propagation of vectors. $N$. pseudobrasiliensis strains were normally cultivated at $37{ }^{\circ} \mathrm{C}$ in brain-heart infusion (Becton Dickinson and Company, Tokyo, Japan) supplemented with $1 \%$ glucose and $1 \%$ glycerol (BHIgg) broth or $2 \%$ agar plates. For the nocardithiocin production, strains were cultivated at $30^{\circ} \mathrm{C}$ in Czapek-Dox (CD) medium consisting of $0.6 \% \mathrm{NaNO}_{3}, 0.052 \% \mathrm{KCl}$,

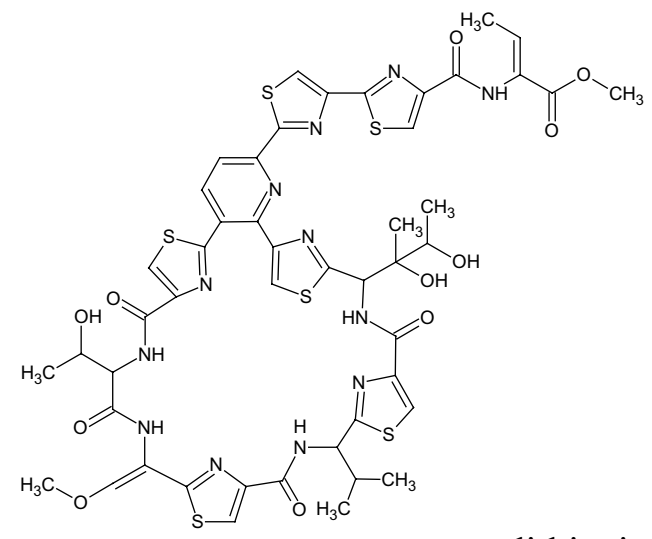

nocardithiocin

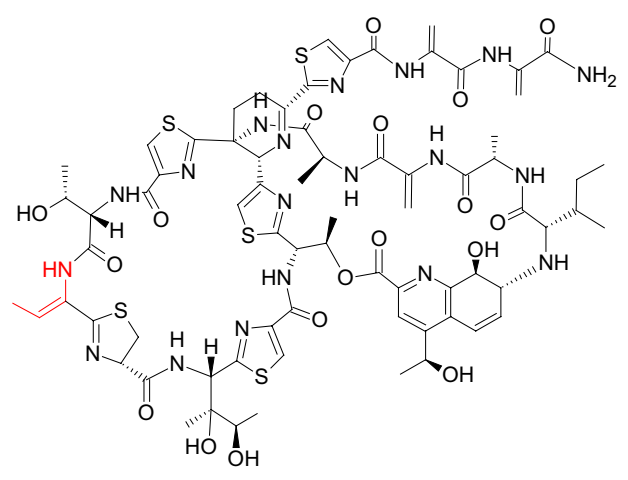

thiostrepton A

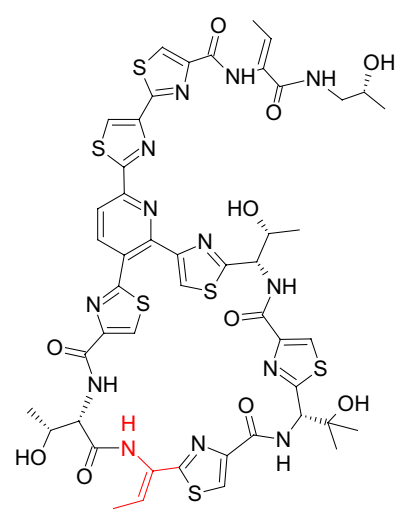

thiocillin I 
a
not: $A \quad B \quad C \quad D \quad E \quad F$ GH $I$
Cyclodehydratase/peptidase
$D$ Methyltransferase
P450 monooxygenase
Precursor peptide
Dehydrogenase
$D$ Cyclodehydratase
$D$ Dehydratase
$\supset$ Transcriptional regulator

$1 \mathrm{~kb}$

\section{b}

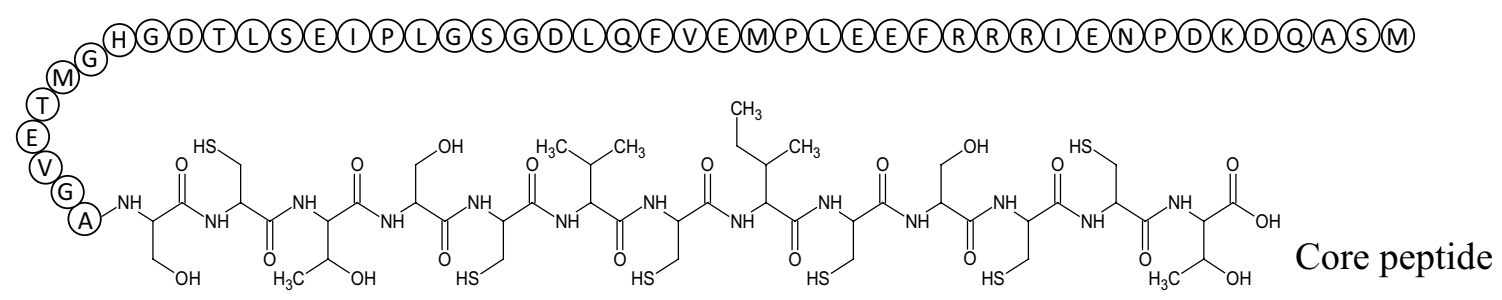

$\begin{array}{llllllllllllll}\mathrm{AA}: & \mathrm{S}_{1} & \mathrm{C}_{2} & \mathrm{~T}_{3} & \mathrm{~S}_{4} & \mathrm{C}_{5} & \mathrm{~V}_{6} & \mathrm{C}_{7} & \mathrm{I}_{8} & \mathrm{C}_{9} & \mathrm{~S}_{10} & \mathrm{C}_{11} & \mathrm{C}_{12} & \mathrm{~T}_{13}\end{array}$

Fig. 2 a Nocardithiocin biosynthetic gene cluster showing the 12 genes notA-notL. b Amino acid sequence of notG. The amino acid in the sixth position (valine, in red) was replaced by the other 19 amino acids

$0.152 \% \mathrm{KH}_{2} \mathrm{PO}_{4}, 1 \%$ glucose, $2 \mathrm{mM} \mathrm{MgSO}_{4}$ and trace elements.

\section{Deletion of notG in Nocardia pseudobrasiliensis}

The not $G$ gene was removed from N. pseudobrasiliensis genome by the double cross-over method, leaving the start and stop codon to retain in-frame translation of the rest of the biosynthetic genes. The not $G$ disruption vector was constructed using upstream and downstream not $G$ fragments that were amplified by PCR using notG-upF (tgcctgcaggtcgagcgtcccaggtgacc) and notG-upR (acgggactactacatgacactatccttcct), and notG-downF (gatagtgtcatgtagtagtcccgtcgtggg) and notG-downR (tcctctagagtcgacgaacaacctggcatc), primer pairs, with $N$. pseudobrasiliensis IFM 0761genomic DNA as a template. Underlined sequences correspond to overlaps used for recombination. Both upand down-stream fragments were ligated into the HincII site of the pNV18.1 vector using the GeneArt Seamless Cloning and Assembly Enzyme Mix (Life Technologies, Tokyo, Japan) according to the manufacturer's protocol.

Transformation of $N$. pseudobrasiliensis was conducted as described previously (Sakai et al. 2015). The first crossover strains were grown on BHIgg plates containing $100 \mu \mathrm{g} /$ $\mathrm{ml}$ neomycin, and further cultivated in BHIgg liquid medium without neomycin for 3 days. Cultures were spread onto BHIgg agar medium without neomycin, and resulting colonies were picked and inoculated into BHIgg plates with and without neomycin. Colonies that grew only on BHIgg plates without neomycin were selected as double cross-over strains. Deletion of not $G$ in the double cross-over strains was confirmed by PCR, Southern blotting, and DNA sequencing.

\section{Expression of Site-Directed notG Mutants}

Native and mutant not $G$ expression vectors were constructed by joining PCR fragment of the not $G$ fragment to the native promoter and $n n r B$ terminator. Site-directed mutagenesis of not $G$ was conducted by PCR using notG-nPF/V60X-R and V60X-F/notG-R-TrrnB primer pairs with $N$. pseudobrasiliensis genomic DNA as the template ( $\mathrm{X}$ indicates any amino acid). The terminator sequence was amplified using the notGTeenBF/TrrnB-R primer pair with the pRU1701 vector as template. All fragments were ligated into the HincII site of pNV18.1 using the GeneArt Seamless Cloning and Assembly Enzyme Mix. All expression vectors were confirmed by sequencing, and primers used for construction are listed in Table S1. 


\section{Detection and Purification of Nocardithiocin Derivatives}

Constructed strains (the $\Delta n o t G$ strain containing a native or mutant not $G$ expression vector) were pre-cultured in BHIgg medium containing neomycin for 3 days at $37{ }^{\circ} \mathrm{C}$, and $1 \%$ of each pre-culture was inoculated into $\mathrm{CD}$ medium containing neomycin and cultivated for 7 days at $30{ }^{\circ} \mathrm{C}$. After cultivation, the same volume of methanol was added to the culture and incubated for at least $1 \mathrm{~h}$. Samples were filtered to remove bacterial cells, and filtrates were evaporated using a rotary evaporator. The remaining water layer was extracted with ethyl acetate, and the ethyl acetate extract was dried in vacuo.

Crude extracts were analyzed to examine the production of nocardithiocin and its derivatives by HPLC (RF-20A/ RF-20Ax, Shimadzu Corp., Kyoto, Japan) with a WakoPack Wakosil-II 3C18 HG column and a gradient elution of $10-100 \%$ acetonitrile in water over $50 \mathrm{~min}$ at a flow rate of $1 \mathrm{ml} / \mathrm{min}$. Eluates were monitored using a fluorescence detector at an extinction wavelength of $350 \mathrm{~nm}$ and an emission wavelength of $450 \mathrm{~nm}$ (RF-20A/RF-20Axs, Shimadzu Corp.) and a mass spectrometer (LCMS-2020, Shimadzu Corp.). Nocardithiocin derivatives were purified from crude extracts by preparative HPLC using a Cosmosil 5C18 MS-II column $(10 \times 150 \mathrm{~mm}$, NACALAI TESQUE, Inc., Kyoto, Japan) with a gradient elution of $30-60 \%$ acetonitrile in water over $20 \mathrm{~min}$ followed by $100 \%$ acetonitrile for $5 \mathrm{~min}$, monitored by a fluorescence detector.

\section{Structural Confirmation}

The crude extracts were first analyzed by LC-MS and the structure of nocardithiocin derivatives were determined by LC-MS/MS analysis. LC-MS/MS was conducted using TripleTOF 6600 hybrid quadrupole-time-of-flight tandem mass spectrometer (Sciex, Concord, Canada) equipped with an electrospray ionization interface. An ODS-80Ts column ( $5 \mu \mathrm{m}, 2.0 \times 150 \mathrm{~mm}$, TOSOH, Tokyo, Japan) was used with mobile phases $0.1 \%$ formic acid in water (A) and $0.1 \%$ formic acid in acetonitrile (B). LC gradient condition was initially $10 \% \mathrm{~B}$ to $100 \% \mathrm{~B}$ (30 min) and $10 \%$ (40 min) at flow rate of $0.2 \mathrm{ml} / \mathrm{min}$. Information dependent acquisition was performed in positive ion mode. MS spectra were acquired from $\mathrm{m} / \mathrm{z} 100$ to $\mathrm{m} / \mathrm{z}$ 2000. The 10 most abundant ions were selected for subsequent fragmentation, and MS/MS spectra were acquired from $\mathrm{m} / \mathrm{z} 100$ to $\mathrm{m} / \mathrm{z} 2000$.

\section{Testing Light and Temperature Stability of Nocardithiocin and Its Derivatives}

Purified compounds were dissolved in DMSO at a final concentration of $0.5 \mathrm{mg} / \mathrm{ml}$ and divided into three parts. One part was covered with foil and kept in the dark, one part was placed under a fluorescent lamp (light) for 4 days at room temperature, and the final part was stored at $4{ }^{\circ} \mathrm{C}$ in the dark. Samples were analyzed by HPLC to quantify the amount of remaining nocardithiocin derivatives. Light stability was calculated by comparing the HPLC peak area of samples stored in the light and dark at room temperature. Similarly, temperature stability was calculated by comparing the dark samples stored at room temperature $\left(30^{\circ} \mathrm{C}\right.$, in summer $)$ and $4{ }^{\circ} \mathrm{C}$ for 4 days.

\section{Testing Solubility of Nocardithiocin and Its Derivatives}

Purified dried samples were dissolved in DMSO or water at a final concentration of $1 \mathrm{mg} / \mathrm{ml}$ and incubated overnight. Insoluble matter was removed by centrifugation, and soluble compounds were quantified using HPLC by comparing the peak areas of compounds in DMSO (completely dissolved $100 \%$ ) and water.

\section{Testing Antimicrobial Activity}

Antimicrobial activity against several bacteria and fungi (Escherichia coli, Staphylococcus aureus, Bacillus subtilis, Micrococcus luteus, Aspergillus niger, Trichophyton mentagrophytes, Candida albicans, and Cryptococcus neoformans) was determined as described previously (Nagai et al. 1993) using the microbroth dilution method. These strains were obtained from the Medical Mycology Research Center (MMRC), Chiba University. The minimum inhibitory concentration (MIC) against mycobacteria was determined using the Clinical Laboratory and Standards Institute (CLSI) protocol (M24-A2). Mycobacterial strains were obtained from the National Institute of Infectious Diseases (NIID). $\mathrm{MIC}$ and $\mathrm{IC}_{50}$ (half maximal inhibitory concentration) values were determined for antimicrobial activity against bacteria and fungi, respectively.

\section{Results}

\section{Deletion of notG in N. pseudobrasiliensis}

Before expressing the mutant not $G$ gene, native not $G$ which encode the precursor peptide was removed from the N. pseudobrasiliensis IFM 0761 genome (Fig. 2). Deletion of not $G$ in $\Delta n o t G$ strains was confirmed by PCR and sequencing (data not shown). HPLC analysis confirmed the absence of nocardithiocin production in $\Delta$ not $G$ strains (Fig. 3). Three $\Delta n o t G$ strains were checked and all of them exhibited the same morphology, so one of them was selected as the host for production of nocardithiocin derivatives. 


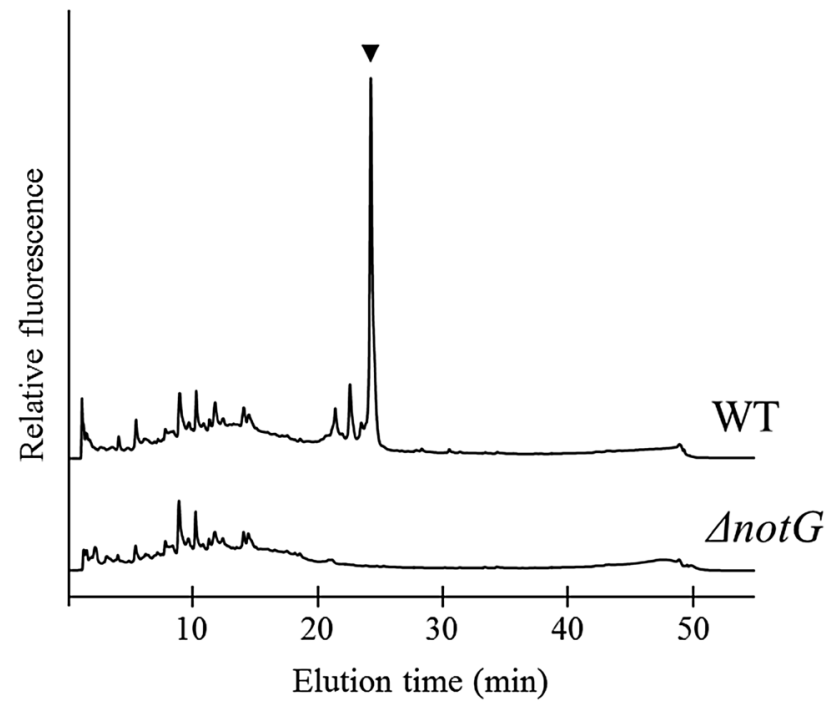

Fig. 3 HPLC analysis of nocardithiocin production in wild-type (WT) and $\Delta n o t G$ strains The nocardithiocin peak is indicated by an arrowhead

\section{Production of Nocardithiocin Derivatives}

The native $n o t G$ expression vector and 19 mutant not $G$ expression vectors with the sixth amino acid $\left(\mathrm{V}_{6}\right)$ replaced by the other 19 amino acids (Fig. 2b) were each transformed into the $\Delta n o t G$ strain, and transformants were cultivated on agar plates. Several colonies were picked to confirm the production of nocardithiocin or its derivatives by HPLC, and the highest producer was selected for subsequent experiments. As shown in Fig. 4, several fluorescence peaks were detected that appeared to be nocardithiocin derivatives. Peaks were significant for ten mutants (A, F, L, I, M, Y, S, T, N, and Q substitutions), indicating successful production of nocardithiocin derivatives. Substitution with A, L, M, S, T, or Q resulted in two or three clear fluorescence peaks with slightly different $\mathrm{m} / \mathrm{z}$ values, were numbered in order of elution time in Fig. 4 . The information of replaced amino acid and MS data from the fluorescence peaks are summarized in Table 1.

\section{Structural Confirmation of Nocardithiocin Derivatives}

Nocardithiocin and its derivatives were purified by preparative HPLC. As shown in Table 1, peptides in which the sixth amino acid was replaced by F, M, Y, and $\mathrm{N}$ did not yield the expected $\mathrm{m} / \mathrm{z}$ values, whereas peptides containing A, L, I, $\mathrm{S}, \mathrm{T}$, and Q matched the expected $\mathrm{m} / \mathrm{z}$ values, although peptides with $\mathrm{A}, \mathrm{L}, \mathrm{S}, \mathrm{T}$, and $\mathrm{Q}$ produced additional unknown peaks. To further confirm the structure of these compounds, LC-MS/MS analysis was performed and the MS/MS results and proposed structures are shown in Fig. S1 and Table S2.

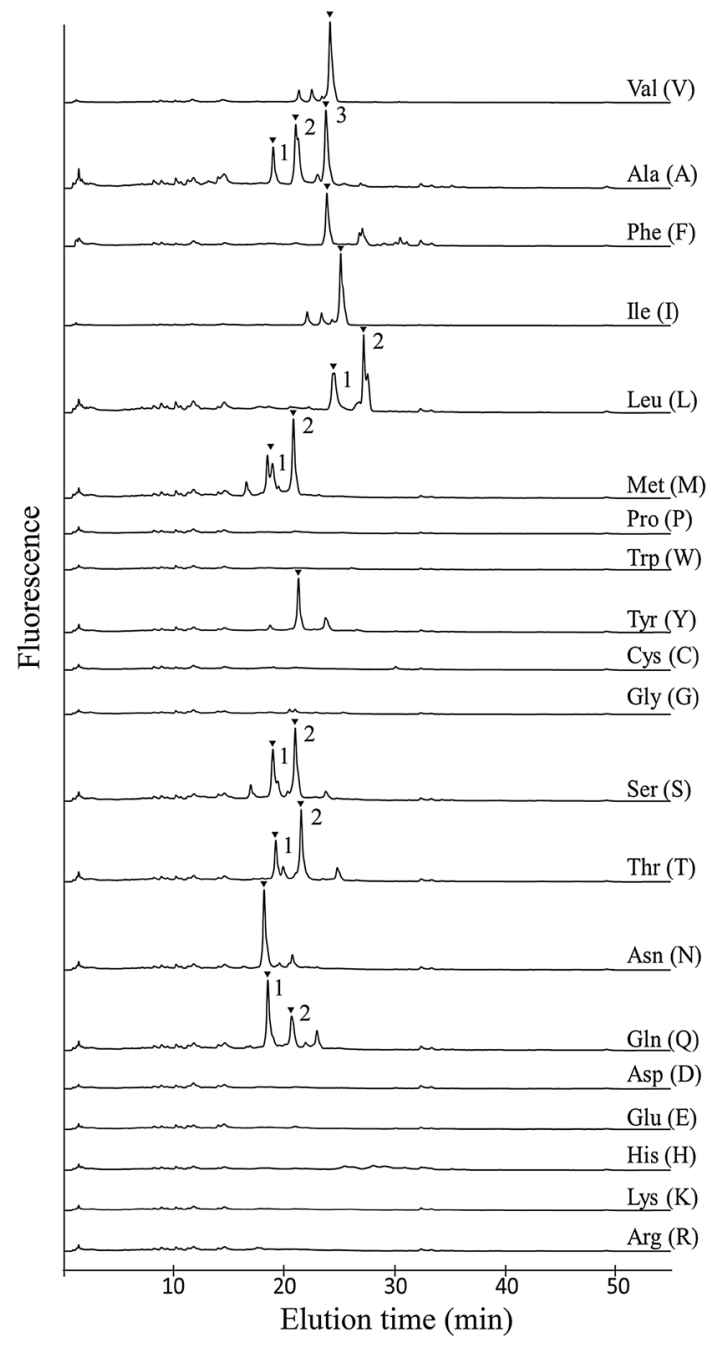

Fig. 4 HPLC analysis of transformants Val (V) indicates native nocardithiocin, and replacement amino acids are shown on the right. Arrowheads indicate purified peaks corresponding to nocardithiocin derivatives and are numbered according to the order of elution

Compounds with the expected $\mathrm{m} / \mathrm{z}$ values (A3, L2, I, S2, $\mathrm{T} 2$, and Q2) produced fragmentation patterns comparable to that of nocardithiocin (i.e., fragment ions were observed with the expected mass shifts). Therefore, these compounds were assumed to be expected nocardithiocin derivatives. The different fragmentation pattern of the other compounds with that of nocardithiocin indicating that they have other structures than expected one amino acid substituted derivatives. These non-expected derivatives were divided into two groups based on their MS/MS fragmentation patterns. Group 1 consists of peptides A1, F, L1, M1, M2, T1, and N, all of which keep the similar structure to nocardithiocin and its expected derivatives. However for example, A1 and M1 have +6 and $+4 \mathrm{~m} / \mathrm{z}$ value different from expected derivative, respectively. This may be caused by the failure of thiazole ring formation next to the substituted amino acid. And the 
Table 1 Aminoacids and LCMS result

\begin{tabular}{|c|c|c|c|c|c|c|}
\hline \multirow[t]{2}{*}{ 6th Amino acid } & \multirow[t]{2}{*}{ Side chain $(-\mathrm{R})$} & \multicolumn{2}{|l|}{ Theoretical } & \multicolumn{3}{|c|}{ Measured $m / z$ value } \\
\hline & & $\begin{array}{l}\text { Chemical for- } \\
\text { mula of deriva- } \\
\text { tives }\end{array}$ & Exact mass & Peak 1 & Peak 2 & Peak 3 \\
\hline \multicolumn{7}{|l|}{ Hydrophobic } \\
\hline \multicolumn{7}{|l|}{ Nonpolar } \\
\hline $\operatorname{Val}(\mathrm{V})$ & $-\mathrm{CH}\left(\mathrm{CH}_{3}\right)_{2}$ & $\mathrm{C}_{48} \mathrm{H}_{48} \mathrm{~N}_{12} \mathrm{O}_{11} \mathrm{~S}_{6}$ & 1161.1963 & 1160.9 & - & - \\
\hline Ala (A) & $-\mathrm{CH}_{3}$ & $\mathrm{C}_{46} \mathrm{H}_{44} \mathrm{~N}_{12} \mathrm{O}_{11} \mathrm{~S}_{6}$ & 1133.3054 & 1138.9 & 1120.85 & 1132.85 \\
\hline Phe (F) & $-\mathrm{CH}_{2} \mathrm{C}_{6} \mathrm{H}_{5}$ & $\mathrm{C}_{52} \mathrm{H}_{50} \mathrm{~N}_{12} \mathrm{O}_{11} \mathrm{~S}_{6}$ & 1209.4013 & 1196.9 & - & - \\
\hline Leu (L) & $-\mathrm{CH}_{2} \mathrm{CH}\left(\mathrm{CH}_{3}\right)_{2}$ & $\mathrm{C}_{49} \mathrm{H}_{50} \mathrm{~N}_{12} \mathrm{O}_{11} \mathrm{~S}_{6}$ & 1175.3851 & 1162.9 & 1174.9 & - \\
\hline Ile (I) & $-\mathrm{CH}\left(\mathrm{CH}_{3}\right) \mathrm{CH}_{2} \mathrm{CH}_{3}$ & $\mathrm{C}_{49} \mathrm{H}_{50} \mathrm{~N}_{12} \mathrm{O}_{11} \mathrm{~S}_{6}$ & 1175.3851 & 1174.9 & - & - \\
\hline Met (M) & $-\mathrm{CH}_{2} \mathrm{CH}_{2} \mathrm{SCH}_{3}$ & $\mathrm{C}_{48} \mathrm{H}_{48} \mathrm{~N}_{12} \mathrm{O}_{11} \mathrm{~S}_{7}$ & 1193.4235 & 1196.85 & 1208.85 & - \\
\hline Pro $(\mathrm{P})$ & $-\mathrm{CH}_{2} \mathrm{CH}_{2} \mathrm{CH}_{2}^{-}$ & $\mathrm{C}_{48} \mathrm{H}_{46} \mathrm{~N}_{12} \mathrm{O}_{11} \mathrm{~S}_{6}$ & 1159.3426 & - & - & - \\
\hline $\operatorname{Trp}(\mathrm{W})$ & $-\mathrm{CH}_{2} \mathrm{C}_{8} \mathrm{H}_{6} \mathrm{~N}$ & $\mathrm{C}_{54} \mathrm{H}_{49} \mathrm{~N}_{13} \mathrm{O}_{11} \mathrm{~S}_{6}$ & 1248.4374 & - & - & - \\
\hline \multicolumn{7}{|l|}{ Hydrophilic } \\
\hline \multicolumn{7}{|l|}{ Polar uncharged } \\
\hline $\operatorname{Tyr}(\mathrm{Y})$ & $-\mathrm{CH}_{2}-\mathrm{C}_{6} \mathrm{H}_{4} \mathrm{OH}$ & $\mathrm{C}_{52} \mathrm{H}_{50} \mathrm{~N}_{12} \mathrm{O}_{12} \mathrm{~S}_{6}$ & 1225.4007 & 1212.95 & - & - \\
\hline Cys (C) & $-\mathrm{CH}_{2} \mathrm{SH}$ & $\mathrm{C}_{46} \mathrm{H}_{44} \mathrm{~N}_{12} \mathrm{O}_{11} \mathrm{~S}_{7}$ & 1165.3704 & - & - & - \\
\hline Gly (G) & $-\mathrm{H}$ & $\mathrm{C}_{45} \mathrm{H}_{42} \mathrm{~N}_{12} \mathrm{O}_{11} \mathrm{~S}_{6}$ & 1119.2788 & - & - & - \\
\hline $\operatorname{Ser}(S)$ & $-\mathrm{CH}_{2} \mathrm{OH}$ & $\mathrm{C}_{46} \mathrm{H}_{44} \mathrm{~N}_{12} \mathrm{O}_{12} \mathrm{~S}_{6}$ & 1149.3048 & 1138.85 & 1148.85 & - \\
\hline Thr $(\mathrm{T})$ & $-\mathrm{CH}(\mathrm{OH}) \mathrm{CH}_{3}$ & $\mathrm{C}_{47} \mathrm{H}_{46} \mathrm{~N}_{12} \mathrm{O}_{12} \mathrm{~S}_{6}$ & 1163.3313 & 1150.85 & 1162.9 & - \\
\hline Asn $(\mathrm{N})$ & $-\mathrm{CH}_{2} \mathrm{CONH}_{2}$ & $\mathrm{C}_{47} \mathrm{H}_{45} \mathrm{~N}_{13} \mathrm{O}_{12} \mathrm{~S}_{6}$ & 1176.3301 & 1163.85 & - & - \\
\hline $\mathrm{Gln}(\mathrm{Q})$ & $-\mathrm{CH}_{2} \mathrm{CH}_{2} \mathrm{CONH}_{2}$ & $\mathrm{C}_{48} \mathrm{H}_{47} \mathrm{~N}_{13} \mathrm{O}_{12} \mathrm{~S}_{6}$ & 1190.3567 & 1179.9 & 1189.9 & - \\
\hline \multicolumn{7}{|c|}{ Negative charge } \\
\hline Asp (D) & $-\mathrm{CH}_{2} \mathrm{COOH}$ & $\mathrm{C}_{47} \mathrm{H}_{44} \mathrm{~N}_{12} \mathrm{O}_{13} \mathrm{~S}_{6}$ & 1177.3149 & - & - & - \\
\hline Glu (E) & $-\mathrm{CH}_{2} \mathrm{CH}_{2} \mathrm{COOH}$ & $\mathrm{C}_{48} \mathrm{H}_{46} \mathrm{~N}_{12} \mathrm{O}_{13} \mathrm{~S}_{6}$ & 1191.3414 & - & - & - \\
\hline \multicolumn{7}{|l|}{ Positive charge } \\
\hline His $(\mathrm{H})$ & $-\mathrm{CH}_{2}-\mathrm{C}_{3} \mathrm{H}_{3} \mathrm{~N}$ & $\mathrm{C}_{49} \mathrm{H}_{46} \mathrm{~N}_{14} \mathrm{O}_{11} \mathrm{~S}_{6}$ & 1199.3667 & - & - & - \\
\hline Lys (K) & $-\left(\mathrm{CH}_{2}\right)_{4} \mathrm{NH}_{2}$ & $\mathrm{C}_{49} \mathrm{H}_{51} \mathrm{~N}_{13} \mathrm{O}_{11} \mathrm{~S}_{6}$ & 1190.3997 & - & - & - \\
\hline $\operatorname{Arg}(\mathrm{R})$ & $-\left(\mathrm{CH}_{2}\right)_{3} \mathrm{NH}-\mathrm{C}(\mathrm{NH}) \mathrm{NH}_{2}$ & $\mathrm{C}_{49} \mathrm{H}_{51} \mathrm{~N}_{15} \mathrm{O}_{11} \mathrm{~S}_{6}$ & 1218.4131 & - & - & - \\
\hline
\end{tabular}

Italic values indicating the expected calculated MS value

"-" Indicates that no obvious LC-MS peak was observed other F, L1, Y, T1 and N showed $-12 \mathrm{~m} / z$ value difference with expected derivatives and M2 showed $-12 \mathrm{~m} / \mathrm{z}$ value difference with M1 may indicating the defective of methyltransferase activity at $\mathrm{S}_{4}$. Group 2 is composed of A2, S1, and Q1 peptides whose fragment patterns were completely different from nocardithiocin and expected derivatives, so we failed to determine their structures but the compounds in this group showed same fragment at lower $\mathrm{m} / \mathrm{z}$ values $(\leq 736)$.

\section{Properties of Nocardithiocin Derivatives}

The light sensitivity of purified compounds was tested and compared with that of native nocardithiocin. In a previous study, nocardithiocin was reported to be unstable in the light (Mukai et al. 2009). However, the results of the present study (Fig. 5a) suggest that neither nocardithiocin nor its derivatives (including unexpected compounds) were light sensitive. Additionally, the stability at room temperature was also examined, and nocardithiocin and its derivatives were shown to be stable (Fig. 5b).

Since the solubility of thiopeptide compounds is very low (Li and Kelly 2010; Just-Baringo et al. 2014b), we tested the solubility of nocardithiocin and its derivatives. Compared the solved amount in DMSO (completely soluble), only $0.14 \%(1.2 \mu \mathrm{M})$ of nocardithiocin was soluble in water. All nocardithiocin derivatives showed a slight improvement in solubility in water (Fig. 6), and Q2 was the most soluble among expected derivative $(3.07 \% ; 25.8 \mu \mathrm{M})$.

\section{Antimicrobial Activity of Nocardithiocin Derivatives}

The antimicrobial activity of nocardithiocin derivatives was tested against several bacteria and fungi (Table 2). Expected nocardithiocin derivatives A3, L2, I, S2, T2, and Q2 retained 
$\mathbf{a}$ a Stability under light

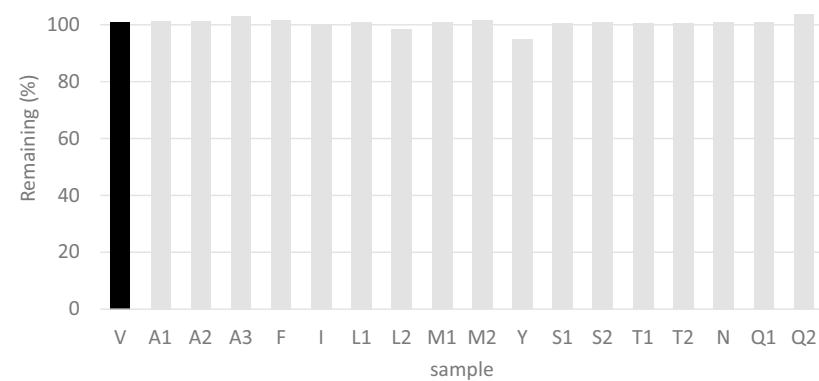

b

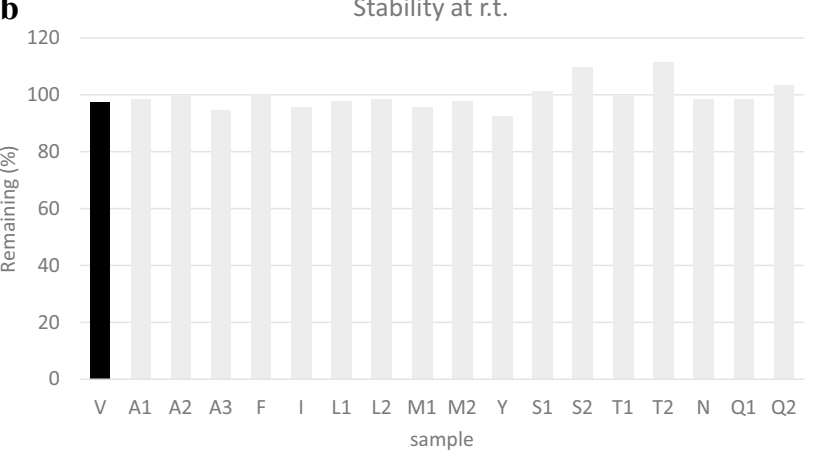

Fig. 5 Analysis of stability tests. a Stability of nocardithiocin and purified compounds in the presence of light. The percentage of the compound remaining was calculated by comparing the peak area following storage in the light and dark. b Stability of nocardithiocin and purified compounds stored at room temperature. The percentage of the compound remaining was calculated by comparing the peak area following storage at ${ }^{\circ} \mathrm{C}$ and room temperature $\left(30{ }^{\circ} \mathrm{C}\right.$, in summer) for 4 days. Nocardithiocin and its derivatives are indicated by orange bars, and compounds belonging to groups 1 and 2 are indicated by green and blue bars, respectively antimicrobial activity, but compounds with unexpected structures lost its activity, except for compound M1. Furthermore, expected derivatives and compounds M1 and M2 exhibited activity against drug-resistant Mycobacterium tuberculosis strains (Table 3). In most cases, native type of nocardithiocin showed stronger antimicrobial activity than its derivatives, but compound I displayed four times and two times greater activity against Bacillus subtilis and Micrococcus luteus, respectively. And compound L2 showed two times higher activity against $M$. luteus (Table 2).

\section{Discussion}

Nocardithiocin is a thiopeptide compound produced by $N$. pseudobrasiliensis (Mukai et al. 2009) that displays powerful activity against drug-resistant M. tuberculosis, making it a promising novel antibacterial drug. However, its clinical use is hampered by low water solubility and light sensitivity, so the property should be improved for further application. Identification of the nocardithiocin biosynthesis gene cluster (Sakai et al. 2015) revealed that it is synthesized through modification of a ribosomally translated precursor peptide, similar to other thiopeptides (Wieland Brown et al. 2009; Liao et al. 2009). This biosynthetic feature prompted us to modify the nocardithiocin structure by altering the amino acid sequence of the precursor peptide to improve its properties.

Firstly, we removed the native not $G$ gene encoding the precursor peptide from the genome of $\mathrm{N}$. pseudobrasiliensis, and the not $G$ deletion strain was used as the host for nocardithiocin derivative production. The

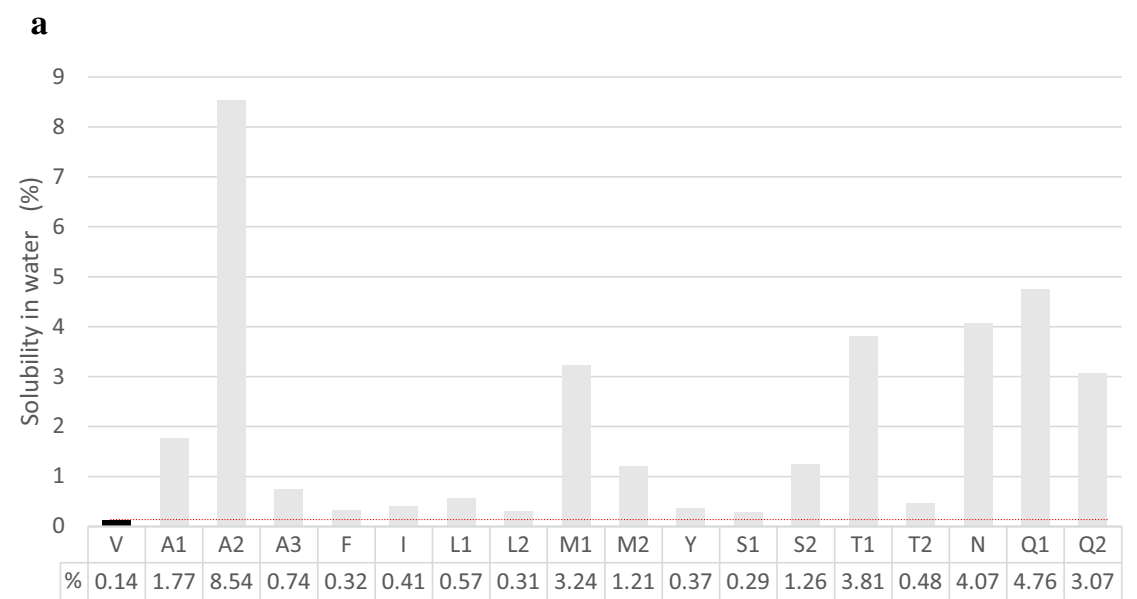

\begin{tabular}{|c|r|}
\hline \multicolumn{1}{|l}{} & \multicolumn{1}{c|}{$\mu \mathrm{M}$} \\
\hline $\mathrm{V}$ & 1.206897 \\
\hline $\mathrm{A} 1$ & 15.5536 \\
\hline $\mathrm{A} 2$ & 76.25 \\
\hline $\mathrm{A} 3$ & 6.537102 \\
\hline $\mathrm{F}$ & 2.675585 \\
\hline $\mathrm{I}$ & 3.492334 \\
\hline $\mathrm{L} 1$ & 4.905336 \\
\hline $\mathrm{L} 2$ & 2.640545 \\
\hline $\mathrm{M} 1$ & 27.0903 \\
\hline $\mathrm{M} 2$ & 10.01656 \\
\hline $\mathrm{Y}$ & 3.052805 \\
\hline $\mathrm{S} 1$ & 2.54833 \\
\hline $\mathrm{S} 2$ & 10.97561 \\
\hline $\mathrm{T} 1$ & 33.13043 \\
\hline $\mathrm{T} 2$ & 4.130809 \\
\hline $\mathrm{N}$ & 34.9957 \\
\hline $\mathrm{Q} 1$ & 40.3732 \\
\hline $\mathrm{Q} 2$ & 25.82002 \\
\hline
\end{tabular}

Fig. 6 Solubility of nocardithiocin and purified compounds in water. a The level of solubility in DMSO was assigned a value of $100 \%$, and peak areas of compounds dissolved in water were compared with peak areas of compounds dissolved in DMSO. b The concentration of dissolved compound was calculated using $\mathrm{m} / \mathrm{z}$ values. Nocardithiocin and its derivatives are indicated by orange bars, and compounds belonging to groups 1 and 2are indicated by green and blue bars, respectively 
Table 2 Antimicrobial activity of nocardithiocin and its derivateives

\begin{tabular}{|c|c|c|c|c|c|c|c|c|c|c|c|c|c|c|c|c|c|c|}
\hline \multirow[t]{2}{*}{ Test organisms } & \multicolumn{18}{|c|}{ MIC and $\mathrm{IC}_{50}$ values for bacteria and fungi, respectively $(\mu \mathrm{g} / \mathrm{ml})$} \\
\hline & $\mathrm{V}$ & $\mathrm{F}$ & $\mathrm{Y}$ & A1 & $\mathrm{A} 2$ & A3 & L1 & L2 & I & M1 & M2 & S1 & S2 & $\mathrm{T} 1$ & $\mathrm{~T} 2$ & $\mathrm{~N}$ & Q1 & Q2 \\
\hline Escherichia coli & $>32$ & $>32$ & $>32$ & $>32$ & $>32$ & $>32$ & $>32$ & $>32$ & $>32$ & $>32$ & $>32$ & $>32$ & $>32$ & $>32$ & $>32$ & $>32$ & $>32$ & $>32$ \\
\hline Staphylococcus aureus & 4 & $>32$ & $>32$ & $>32$ & $>32$ & $>32$ & $>32$ & 16 & 16 & $>32$ & $>32$ & $>32$ & $>32$ & $>32$ & 16 & $>32$ & $>32$ & $>32$ \\
\hline Bacillus subtilis & 4 & $>32$ & $>32$ & $>32$ & $>32$ & $>32$ & $>32$ & 16 & 1 & $>32$ & $>32$ & $>32$ & $>32$ & $>32$ & $>32$ & 16 & 32 & $>32$ \\
\hline Micrococcus luteus & 32 & $>32$ & $>32$ & $>32$ & $>32$ & $>32$ & $>32$ & 16 & 16 & $>32$ & $>32$ & $>32$ & $>32$ & $>32$ & $>32$ & $>32$ & $>32$ & $>32$ \\
\hline \multicolumn{19}{|l|}{ Gordonia bronchialis } \\
\hline IFM 0150 & 2 & $>32$ & $>32$ & $>32$ & $>32$ & $>32$ & $>32$ & 16 & 8 & $>32$ & $>32$ & $>32$ & $>32$ & $>32$ & 32 & $>32$ & $>32$ & $>32$ \\
\hline \multicolumn{19}{|l|}{ Aspergillus niger } \\
\hline IFM 62678 & 8 & $>32$ & $>32$ & $>32$ & $>32$ & 32 & $>32$ & 16 & 32 & 32 & $>32$ & $>32$ & $>32$ & $>32$ & $>32$ & $>32$ & $>32$ & $>32$ \\
\hline \multicolumn{19}{|l|}{ Candida albicans } \\
\hline IFM 62680 & $>32$ & $>32$ & $>32$ & $>32$ & $>32$ & $>32$ & $>32$ & $>32$ & $>32$ & $>32$ & $>32$ & $>32$ & $>32$ & $>32$ & $>32$ & $>32$ & $>32$ & $>32$ \\
\hline \multicolumn{19}{|l|}{ Cryptococcus neoformans } \\
\hline IFM 62681 & 32 & $>32$ & $>32$ & $>32$ & $>32$ & $>32$ & $>32$ & $>32$ & 32 & $>32$ & $>32$ & $>32$ & $>32$ & $>32$ & $>32$ & $>32$ & $>32$ & $>32$ \\
\hline
\end{tabular}

The itaic values indicated the stronger activity than nocardithiocin

mutant fragment of not $G$ were prepared by PCR-based site directed mutagenesis method and expressed under the $\operatorname{not} G$ native promoter, because production of derivatives under the control of constitutive promoter PermE (Labes et al. 1997) was much lower (Fig. S2) than native not $G$ promoter. Expression of not $G$ under the control of PermE was actually higher than the native promoter, suggesting that coordinated regulation with other genes in the cluster is important for optimal nocardithiocin production. Therefore, further improvement of nocardithiocin production may be achieved by modifying the expression levels of the transcriptional regulator notD in the gene cluster.

Among the 19 amino acid substituted derivatives, 10 amino acid produced clear HPLC fluorescent peaks under nocardithiocin detection condition, but nine (P, W C, G, D, E, H, K, and R) did not show any significant compound production (Fig. 3). The imino acid structure of $\mathrm{P}$, the large side chain of $\mathrm{W}$, and the small side chain of $\mathrm{G}$ may prevent the enzymatic reaction(s) required to synthesize nocardithiocin derivatives. Similarly, a negative (D and E) or positive (H, $\mathrm{K}$, and R) charge could disrupt derivative synthesis. Finally, the sulfur-containing side chain of $\mathrm{C}$ could form a thiazole ring following the action of cyclodehydratase, resulting in three adjacent thiazoles at positions $\mathrm{C}_{5}$ and $\mathrm{C}_{7}$, which could explain the failure to synthesize this derivative. Several reports showed the preference of amino acids depending on the replaced position in thiopeptides (Young et al. 2012; Zhang et al. 2012; Tran et al. 2017).

Substitution with A, L, M, S, T, or Q resulted in the production of two or three major compounds, implying that nocardithiocin biosynthetic enzymes or other enzymes might have the ability to produce diverse compounds from nocardithiocin precursor peptides with altered amino acid sequences. Other than the compound M2, expected nocardithiocin derivatives eluted later in the elution profile (Table 1). Comparison of the MS/MS fragmentation patterns with that of nocardithiocin $(\mathrm{V})$ confirmed that $\mathrm{A} 3, \mathrm{~L} 2$, I, S2, T2, and Q2 were the expected derivatives (Fig. S1). Although the exact structures have not been determined, unexpected compounds were classified into two groups based on their MS/MS fragmentation patterns. The fragmentation pattern of group 1 compounds suggested that their similar structure with nocardithiocin derivatives because several MS/MS fragments were coincident with those of nocardithiocin (Table S2). The speculated structure of group 1 compounds from MS/MS spectrum indicated the partial or defective reaction of thiazole formation or addition of methyl group (Fig. S1). The size of amino acid residue may cause this incomplete reaction. The properties of the purified compounds were tested, and none of them displayed the previously reported light sensitivity (Mukai et al. 2009). Although nocardithiocin and its derivatives in crude samples appeared as single peaks in the HPLC analysis, purified samples contained two separated peaks (Fig. S3). After single peaks were collected by HPLC, collected samples showed two separate peaks with similar proportions in the 1st HPLC. This phenomenon could have been interpreted as light-induced degradation in the previous report. Furthermore, the previous study used a glass tubes for storing nocardithiocin samples, and nocardithiocin may be adsorbed to glass tubes due to its hydrophobic and basic nature.

Nocardithiocin and produced compounds were not degraded under light irradiation, so light sensitivity remains as major limitation of clinical use. However the produced derivatives remained poorly soluble in water (Fig. 5). In previous report, water-soluble analogues of nocathiacin prepared by semi-synthesis retained antimicrobial activity (Xu et al. 2013). In that report, modification of side chains 


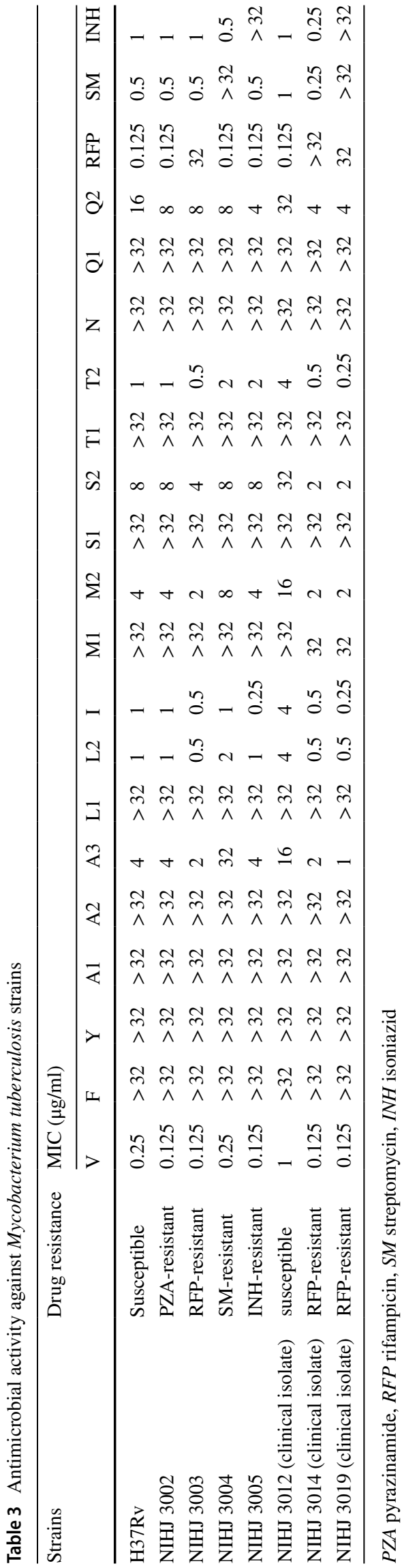

at the tail end of the peptide improved its water solubility, and similar modifications could also enhance the water solubility of nocardithiocin derivatives without diminishing antimicrobial activity.

The antimicrobial activity of nocardithiocin and its derivatives was tested against several microbes. Among the 17 successfully purified compounds, 10 showed some antimicrobial activity. While native nocardithiocin displayed higher activity than most of its derivatives, compounds L2 and I displayed slightly higher antimicrobial activity against Gram-positive bacteria (Table 2). Young et al. (2012) also reported the amino acid replacement of G37468 (T2C) increased twofold improved activity against $B$. subtilis implying the potential of amino acid replacement of thiopeptide compounds for improvement of its antimicrobial activity. Compounds L2, I, and T2 that exhibited relatively strong antimicrobial activity share similar side chains at the sixth position to that present in nocardithiocin $\left(\mathrm{V}_{6}\right)$, and similarly low water solubility. This result indicated that a branched methyl group at the sixth position of nocardithiocin makes some contribution to its antimicrobial activity. Although the sixth amino acid was chosen for mutation based on the assumption that it is not crucial for antimicrobial activity, substitution clearly gave a significant impact to antimicrobial activity. The prepared compounds which have different structure with expected nocardithiocin derivatives did not display clear antimicrobial activity may implying the importance of methyl group on $\mathrm{S}_{4}$ or proper thiazole ring formation for nocardithiocin activity.

In this report, among 13 amino acid residue of nocardithiocin, only the sixth amino acid was substituted, and many more derivatives could be prepared by replacing other position of amino acid residue(s) and/or by using unusual amino acids other than the 19 canonical amino acids found in native proteins (Luo et al. 2016). The relationship of structure-activity could not be deeply analyzed yet, increased information will facilitate the rational design of nocardithiocin derivatives with desirable properties in future studies (Wolf et al. 2014).

Acknowledgements We thank the National Institute of Infectious Diseases (NIID) for providing M. tuberculosis strains.

Funding This study was funded by a JSPS KAKENHI award (Grant No. JP25305012).

\section{Compliance with Ethical Standards}

Conflict of interest All the authors declare that they have no conflict of interest.

Research Involving Human Participants and/or Animals This article does not contain any studies with human participants or animal performed by any of the authors. 
Open Access This article is distributed under the terms of the Creative Commons Attribution 4.0 International License (http://creativeco mmons.org/licenses/by/4.0/), which permits unrestricted use, distribution, and reproduction in any medium, provided you give appropriate credit to the original author(s) and the source, provide a link to the Creative Commons license, and indicate if changes were made.

\section{References}

Acker MG, Bowers AA, Walsh CT (2009) Generation of thiocillin variants by prepeptide gene replacement and in vivo processing by Bacillus cereus. J Am Chem Soc 131(48):17563-17565

Arndt HD, Schoof S, Lu JY (2009) Thiopeptide antibiotic biosynthesis. Angew Chem Int Ed 48(37):6770-6773

Bowers AA, Acker MG, Koglin A, Walsh CT (2010) Manipulation of thiocillin variants by prepeptide gene replacement: structure, conformation, and activity of heterocycle substitution mutants. J Am Chem Soc 132(21):7519-7527

Gross S, Nguyen F, Bierschenk M, Sohmen D, Menzel T, Antes I, Wilson D, Bach T (2013) Amythiamicin D and related thiopeptides as inhibitors of the bacterial elongation factor EF-Tu: modification of the amino acid at carbon atom $\mathrm{C}_{2}$ of ring $\mathrm{C}$ dramatically influences activity. ChemMedChem 8:1954-1962

Just-Baringo X, Bruno P, Pitart C, Vila J, Albericio F, Álvarez M (2014a) Dissecting the structure of thiopeptides: assessment of thiazoline and tail moieties of baringolin and antibacterial activity optimization. J Med Chem 57:4185-4195

Just-Baringo X, Albericio F, Álvarez M (2014b) Thiopeptide antibiotics: retrospective and recent advances. Mar Drugs 12(1):317-351

Just-Baringo X, Albericio F, Álvarez M (2014c) Thiopeptide engineering: a multidisciplinary effort towards future drugs. Angew Chem Int Ed Engl 53(26):6602-6616

Kelly WL, Pan L, Li C (2009) Thiostrepton biosynthesis: prototype for a new family of bacteriocins. J Am Chem Soc 131(12):4327-4334

Labes G, Bibb M, Wohlleben W (1997) Isolation and characterization of a strong promoter element from the Streptomyces ghanaensis phage I19 using the gentamicin resistance gene (aacC1) of Tn 1696 as reporter. Microbiology 143:1503-1512

Li C, Kelly WL (2010) Recent advances in thiopeptide antibiotic biosynthesis. Nat Prod Rep 27:153-164

Li C, Zhang F, Kelly WL (2011) Heterologous production of thiostrepton A and biosynthetic engineering of thiostrepton analogs. Mol Biosyst 7(1):82-90

Li C, Zhang F, Kelly WL (2012) Mutagenesis of the thiostrepton precursor peptide at Thr7 impacts both biosynthesis and function. Chem Commun 48(4):558-560

Liao R, Duan L, Lei C, Pan H, Ding Y, Zhang Q, Chen D, Shen B, Yu Y, Liu W (2009) Thiopeptide biosynthesis featuring ribosomally synthesized precursor peptides and conserved posttranslational modifications. Chem Biol 16(2):141-147

Luo X, Zambaldo C, Liu T, Zhang Y, Xuan W, Wang C, Reed SA, Yang PY, Wang RE, Javahishvili T, Schultz PG, Young TS (2016)
Recombinant thiopeptides containing noncanonical amino acids. Proc Natl Acad Sci USA 113(13):3615-3620

Morris RP, Leeds JA, Naegeli HU, Oberer L, Memmert K, Weber E, LaMarche MJ, Parker CN, Burrer N, Esterow S, Hein AE, Schmitt EK, Krastel P (2009) Ribosomally synthesized thiopeptide antibiotics targeting elongation factor Tu. J Am Chem Soc 131(16):5946-5955

Mukai A, Fukai T, Hoshino Y, Yazawa K, Harada K, Mikami Y (2009) Nocardithiocin, a novel thiopeptide antibiotic, produced by pathogenic Nocardia pseudobrasiliensis IFM 0757. J Antibiot 62(11):613-619

Nagai H, Mikami Y, Yazawa K, Gonoi T, Yasumoto T (1993) Biological activities of novel polyether antifungals, gambieric acids A and B from a marine dinoflagellate Gambierdiscus toxicus. J Antibiot 46(3):520-522

Naidu BN, Sorenson ME, Matiskella JD, Li W, Sausker JB, Zhang Y, Connolly TP, Lam KS, Bronson JJ, Pucci MJ, Yang H, Ueda Y (2006) Synthesis and antibacterial activity of nocathiacin I analogues. Bioorg Med Chem Lett 16(13):3545-3549

Nicolaou KC, Nevalainen M, Zak M, Bulat S, Bella M, Safina BS (2003) Synthetic studies on thiostrepton: construction of thiostrepton analogues with the thiazoline-containing macrocycle. Angew Chem Int Ed Engl 42(29):3418-3424

Sakai K, Komaki H, Gonoi T (2015) Identification and functional analysis of the Nocardithiocin Gene cluster in Nocardia pseudobrasiliensis. PLoS ONE 10(11):e0143264

Tran HL, Lexa KW, Julien O, Young TS, Walsh CT, Jacobson MP, Wells JA (2017) Structure-activity relationship and molecular mechanics reveal the importance of ring entropy in the biosynthesis and activity of a natural product. J Am Chem Soc 139(7):2541-2544

Wieland Brown LC, Acker MG, Clardy J, Walsh CT, Fischbach MA (2009) Thirteen posttranslational modifications convert a 14-residue peptide into the antibiotic thiocillin. Proc Natl Acad Sci USA 106(8):2549-2553

Wolf A, Schoof S, Baumann S, Arndt HD, Kirschner KN (2014) Structure-activity relationships of thiostrepton derivatives: implications for rational drug design. J Comput Aided Mol Des 28(12):1205-1215

Xu L, Farthing AK, Dropinski JF, Meinke PT, McCallum C, Hickey E, Liu K (2013) Synthesis and antibacterial activity of novel water-soluble nocathiacin analogs. Bioorg Med Chem Lett 23(1):366-369

Young TS, Dorrestein PC, Walsh CT (2012) Codon randomization for rapid exploration of chemical space in thiopeptide antibiotic variants. Chem Biol 19(12):1600-1610

Zhang F, Kelly WL (2015) Saturation mutagenesis of TsrA Ala4 unveils a highly mutable residue of thiostrepton A. ACS Chem Biol 10(4):998-1009

Publisher's Note Springer Nature remains neutral with regard to jurisdictional claims in published maps and institutional affiliations. 